\title{
Potential Protective Effect of Sickle Cell Gene Allele on HIV Infection
}

\author{
James M Oleske*, Hans ML Spiegel, Julie Makani, Anthony Scolpino, Sukhwinder Singh, Keneil Shah, Garrett \\ Gianneschi, James Koola, Robert McLoughlin, Paul Palumbo, Arry Dieudonne, Onajovwe Fofah and Franklin \\ Desposito
}

Department of Pediatrics, Rutgers New Jersey Medical School, USA

Submission: January 24, 2017; Published: February 09, 2017

*Corresponding author: James M Oleske MD MPH, Department of Pediatrics, Rutgers New Jersey Medical School, 185 South Orange Ave, Newark, NJ 07103, USA, Tel: 9739721504; Email: oleskejm@njms.rutgers.edu

\section{Short Communication}
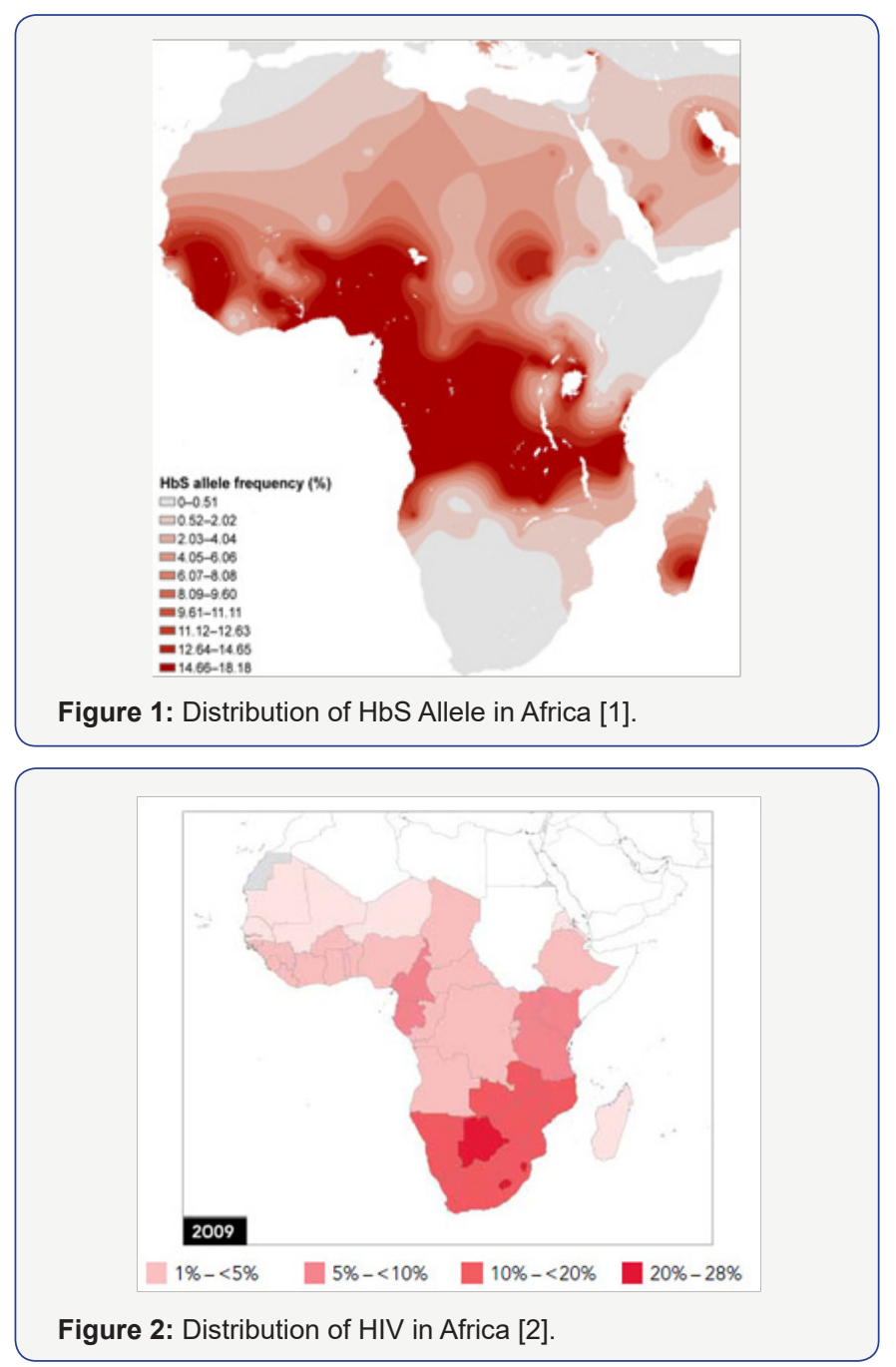

Both Sickle Cell Disease and HIV Infection have overlapping worldwide distributions, with Africa being the epicenter for these two conditions (Figure $1 \& 2$ ) [1,2]. Sickle Cell Disease is a genetic condition affecting chromosome 11 in which homozygous recessive individuals will have significant negative consequences secondary to sickling phenomenon of their red blood cells, while those that are heterozygous have a survival advantage based on a well-described resistance to malaria [3]. The Human Immunodeficiency Virus takes advantage of surface proteins on white cells, resulting in lytic destruction and consequent CD4+ lymphopenia and immunosuppression [4]. Both diseases have significant morbidity and mortality, with limited treatment options. Nevertheless, observations in our pediatric HIV program in Newark, NJ, one of the first epicenters for Perinatal HIV Infection (PHIV), suggested that children with sickle cell disease infrequently were infected with HIV despite being from a high-risk population5 (Table 1) [5]. Current understanding of the interplay of genetic impact on surface membranes supports the idea that genetic variations might impact susceptibility to infectious diseases. Similar to its protective effect against malaria, sickle cell trait may provide protection against acquisition of HIV infection through changes in CXCR4 and CCR5 receptors on CD4+ lymphocytes, possibly blocking viral entry and infection [6]. Potential mechanisms for this disparity might provide better understanding and approaches to HIV infection based on sickle cell status.

Table 1: HIV Status by Hemoglobinopathy Status among Perinatal HIVExposed Infants (Newark, NJ 1993-2003) [5]. * $\mathrm{P}=0.48$ by Fisher's Exact (odds ratio $=0.62 ; 95 \%$ Confidence interval $=0.21$ to 1.8 ).

\begin{tabular}{|c|c|c|c|}
\hline HIV/Hemoglobin Status & HIV+ & HIV- & Total \\
\hline Hemoglobinopathy (AS) & $4\left(8.3 \%^{*}\right)$ & 44 & 48 \\
\hline No Hemoglobinopathy (AA) & $40\left(14.5 \%^{*}\right)$ & 236 & 276 \\
\hline Total: & $44\left(13.6 \%^{*}\right)$ & 280 & 324 \\
\hline
\end{tabular}

The authors have had a long standing hypothesis that the Sickle Cell Gene Allele (SCGA) may confer a protective effect against acquisition and/or progression of HIV infection. Rutgers NJMS in Newark, NJ has long been a center of PHIV care and research since the onset of the HIV pandemic, developing domestic and global clinical, educational and research expertise in PHIV infection 
leading to the control and subsequent prevention of PHIV in the US. Among our large population of PHIV African American children, we noted a lower than expected occurrence of Sickle Cell Hemoglobinopathy ( $\mathrm{SCH}$ ) suggesting relative protection against PHIV acquisition, and by inference, progression. However, though the data from the Newark PHIV program is suggestive of the potential protective effect of the SCGA, it lacks the patient base needed to achieve sufficient statistical power to confirm this potential association [5]. Sub-Saharan Africa has approximately $64 \%$ of the world's population living with HIV, $91 \%$ of children under 15 years of age living with HIV, and approximately 10-40\% of the world's SCD population [1,7]. The population distribution of individuals in Africa with HbS allele and HIV are seemingly non-overlapping, supporting preliminary data from our pediatric cohort $[1,2,5]$. This non-overlapping distribution is unexpected, given the high prevalence of both Sickle Cell Disease and HIV in Africa. South Africa, having a low distribution of SCGA has one of the higher concentrations of HIV infectivity in Africa, confirming the significance of these observations. These findings should stimulate further investigation into the molecular basis for this protective effect, which could influence the direction of new therapies (drug, genetic, and immune-based approaches) for the treatment and prevention of HIV.

There are three lines of evidence that suggest Sickle Cell Hemoglobin ( $\mathrm{SCH}$ ) has a protective effect against HIV acquisition/ progression. First, anecdotal observations by investigators at Rutgers NJMS noted the above, which suggested lower transmission rates of PHIV among HIV exposed neonates with SCGA compared with those without [5]. Second, an epidemiological study by Nouraie et al. [8] documented a two-fold lower risk of HIV infection and comorbidity in patients with SCD among African-American adult patient hospital discharges. This effect was observed over a 13-year period in over 400,000 patient records. Further, the authors of this article offered several possible mechanisms for the apparent impact of SCGA on the course of HIV disease including up-regulation of heme oxygenase-1, hypoxia related to the anemia, higher expression of inflammatory cytokines, inhibition of HIV transcription in the presence of reduced iron, as well as use of hydroxyurea in SCD patients. Third, SCGA is already documented to have protective effects against other infectious diseases, such as Malaria. Although this conferred protection occurs by conformational changes in the hemoglobin molecule by the SCGA inhibiting the penetration and proliferation of the Malaria Parasite in RBCs, there may be other characteristics of this gene allele product, expressed on lymphocytes and other white blood cells that may also confer protection against HIV attachment, penetration and/or proliferation [9].

A possible mechanism of protection could exist within the genome of patients with SCGA. Past literature has already elucidated the mechanism by which certain Caucasians of Northern European descent have conferred resistance to HIV [10]. These persons possess a 32-base-pair deletion on the CCR5 white blood cell surface protein, one of two chemoreceptors utilized by HIV-
1 to enter the leukocyte. The CCR5 32 mutation found in these individuals results in a dysfunctional surface protein, preventing the virus from entering the host [11]. In the case of individuals with SCGA, the authors further propose that the TRIM5 $\alpha$ protein could play a role in the protective effect. This protein disassembles and degrades viral capsid binding, preventing the pre-integration complex from arriving at the nucleus, thus interfering with reverse transcription [12]. A study in 2004 conducted by Stremlau et al. [13] identified TRIM5 $\alpha$ as the blocking factor responsible for blocking HIV-1 strains from infecting Old World Monkeys13. Subsequent research has shown that rhesus TRIM5 $\alpha\left(\right.$ TRIM $5 \alpha_{\mathrm{rh}}$ ) appears to be more stable, and thus more potent, than human TRIM5 $\alpha$ (TRIM5 $\alpha_{\text {hu }}$ ), lending a reason as to why the majority of humans are immune to HIV-1 infection. Examination into the effect of various polymorphisms in TRIM $5 \alpha_{\text {hu }}$ revealed differing frequencies of HIV infection among African American cohorts. The TRIM5 $\alpha 136 \mathrm{Q}$ polymorphism-indicating a glutamate at residue 136 in the TRIM5 $\alpha$ protein - was identified as possessing a potential protective effect, as it was found at a greater frequency in the High-Risk Exposed Uninfected African American population [14]. Furthermore, the TRIM $5 \alpha$ gene locus is found in close proximity to the HBB gene locus on human chromosome 11, lending the possibility that linkage disequilibrium interaction between the two could exist. Because a large proportion of African American individuals possess the SCGA, the authors further propose that a potential link between SCGA and TRIM5 $\alpha 136 \mathrm{Q}$ may explain the lower-than-expected proportion of HIV-infected individuals with the SCGA.

While a recent systematic review concluded that SCD slows the progression of HIV into AIDS, and conversely HIV infection complicates the course of patients with SCD [15], no well controlled study of a relationship between the presence of SCGA and the acquisition or progression of HIV infection has been conducted. Such a study would identify the sickle cell status (SS vs. SC vs. SA vs. AA) in HIV-infected cohorts and, conversely, the HIV status in identified sickle cell cohorts. The population of HIV-infected patients who carry the SCGA would be the target population of a prospective study to determine the impact associated with the comorbidity of HIV infection and SCGA status. The high prevalence of SCGA and HIV infection in the Sub-Saharan African population and the preliminary observations of a possible impact of SCGA status and HIV incidence as well as the progression of HIV-1 disease, justifies further study of the possible interaction between these two significant global health problems. The results of such a study would have a major impact on the management and follow-up of individuals followed in these countries as well as encourage collaboration with and within these resource-constrained areas of the world to address the global health challenges experienced by much of the world's population.

\section{Acknowledgement}

Barry Dashefsky MD, Bart Holland PhD, MPH, François Dabis MD, MPH, Nathalie De-Rekeneire MD and Said Aboud MD are thanked for their contributions to this work. 


\section{Author Contributions}

JO made original observation that SCD appeared in his population of PHIV infants to be underrepresented. HS assisted in recruiting international support for this hypothesis. JM consulted on presence of PHIV in her large cohort of SCD patients. AS provided technical support in data evaluation. KS, GG, JK, RM, PP, $\mathrm{AD}, \mathrm{OF}$, and FD provided technical support in data analysis and manuscript preparation.

\section{References}

1. Grosse SD, Odame I, Atrash HK, Amendah DD, Piel FB, et al. (2011) Sickle cell disease in Africa: a neglected cause of early childhood mortality. Am J Prev Med 41(6S4): S398-S405.

2. http://www.unaids.org/globalreport/documents/20101123_ GlobalReport_Chap2_em.pdf

3. Aidoo M, Terlouw DJ, Kolczak MS, McElroy PD, ter Kuile FO, et al. (2002) Protective Effects of the Sickle Cell Gene Against Malaria Morbidity and Mortality. The Lancet 359(9314): 1311-1312.

4. Chan DC, Kim PS (1998) HIV Entry and Its Inhibition. Cell 93(5): 681684

5. Patel R, Palmieri A, Ezeanolue E, Wodi P, Desposito F, et al. (2005) Transmission rates of perinatally acquired (PNA) HIV infection in newborns with and without sickle cell hemoglobinopathy ( $\mathrm{SCH}$ ) Eastern Society for Pediatric Research Meeting $17^{\text {th }}$ annual meeting Hyatt Regency, Old Greenwich, CT, USA.

6. Berger EA, Doms RW, Fenyö EM, Korber BT, Littman DR, et al. (1998) A New Classification for HIV-1. Nature 391(6664): 240.

7. Makani J, Cox SE, Soka D, Komba AN, Oruo J, et al. (2011) Mortality in sickle cell anemia in Africa: a prospective cohort study in Tanzania. PLoS One 6(2): e14699.

This work is licensed under Creative Commons Attribution 4.0 Licens DOI: 10.19080/AJPN.2017.02.555600
8. Nouraie M, Nekhai S, Gordeuk VR (2012) Sickle cell disease is associated with decreased HIV but higher HBV and HCV comorbidities in US hospital discharge records: a cross-sectional study. Sex Transm Infect 88(7): 528-533.

9. Kaur P, et al. (1983) Polymorphonuclear leukocyte chemotaxis defects in children with sickle cell anemia. American Academy of Allergy and Immunology, 39th Annual Meeting, Hollywood, FL, USA.

10. Hummel S, Schmidt D, Kremeyer B, Herrmann B, Oppermann M (2005) Detection of the CCR5- $\Delta 32$ HIV resistance gene in Bronze Age skeletons. Genes Immun 6(4): 371-374.

11. Marmor M, Sheppard HW, Donnell D, Bozeman S, Celum C, et al. (2001) Homozygous and Heterozygous CCR5- $\Delta 32$ Genotypes Are Associated With Resistance to HIV Infection. J Acquir Immune Defic Syndr 27(5): 472-481.

12. Richardson MW, Guo L, Xin F, Yang X, Riley JL (2014) Stabilized Human TRIM5 $\alpha$ Protects Human T Cells From HIV-1 Infection. Mol Ther 22(6): 1084-1095.

13. Stremlau M, Owens CM, Perron MJ, Kiessling M, Autissier P, et al (2004) The cytoplasmic body component TRIM5 alpha restricts HIV-1 infection in Old World Monkeys. Nature 427(6977): 848-853.

14. Javanbakht H, An P, Gold B, Petersen DC, O'Huigin C, et al. (2006) Effects of human TRIM5 $\alpha$ polymorphisms on antiretroviral function and susceptibility to human immunodeficiency virus infection. Virology 354(1): 15-27.

15. Owusu ED, Visser BJ, Nagel IM, Mens PF, Grobusch MP (2015) The Interaction Between Sickle Cell Disease and HIV Infection: A Systematic Review. Clin Infect Dis 60(4): 612-626.

Your next submission with Juniper Publishers will reach you the below assets

- Quality Editorial service

- Swift Peer Review

- Reprints availability

- E-prints Service

- Manuscript Podcast for convenient understanding

- Global attainment for your research

- Manuscript accessibility in different formats

( Pdf, E-pub, Full Text, Audio)

- Unceasing customer service

Track the below URL for one-step submission https://juniperpublishers.com/online-submission.php 